\title{
Performance and intestinal characteristics of broiler chicken fed diet with glutamine in the diet without anticoccidials agents
}

\author{
Desempenho e características intestinais de frangos de corte alimentados com dieta \\ com glutamina sem agentes anticoccidianos
}

NASCIMENTO, Gisele Mendanha ${ }^{1}$; LEANDRO, Nadja Susana Mogyca ${ }^{1}$; CAFÉ, Marcos Barcellos ${ }^{1}$; STRINGHINI, José Henrique ${ }^{1}$; ANDRADE, Maria Auxiliadora ; MARTINEZ, Karina Ludovico de Almeida ${ }^{2}$; MELLO, Heloisa Helena de Carvalho ${ }^{1}$; MASCARENHAS, Alessandra Gimenez ${ }^{1}$

\footnotetext{
${ }^{1}$ Universidade Federal de Goiás, Escola de Veterinária e Zootecnia, Departamento De Produção Animal, Goiânia, Goiás, Brasil, mogyca@ufg.br

${ }^{2}$ Universidade Federal de Goiás, Campus Jataí, Jataí, Goiás, Brasil
}

\section{SUMMARY}

Five hundred commercial male Cobb broilers were allotted in a randomized blocks design with five treatments, four replicates and 25 chicks per experimental unit in order to evaluate the effects of adding L-glutamine to the diet with no anticoccidial agents and growth promoters. Experimental diets contained L-glutamine at different levels $(0.0 ; 5.0 ; 10.0$; 15.0 or $20.0 \mathrm{~g} / \mathrm{kg}$ ), through the experimental period. Experiment was conducted with broiler chicken from 1 to 42 days old. The parameters evaluated were feed intake, feed conversion ratio, body weight gain, mortality, digestibility coefficients of dry matter, crude protein and ether extract, carcass yield and intestinal mucosa structure of small intestine. The data obtained were submitted to polynomial regression analysis. Means were compared using Tukey test.Was considered a type I error set at $\mathrm{P} \leq 0.05$. The level of L-glutamine in the diet influenced feed conversion ratio of broilers at 1-7 days old, which was improved at $10.0 \mathrm{~g} / \mathrm{kgL}$ glutamine. Carcass yield and digestibility coefficients of the diet were not affected by the levels of glutamine in the diet. Adding L-glutamine influenced crypt depth in small intestine of broilers at 18 and 42 days old. It is recommended the addition of $10.0 \mathrm{~g} / \mathrm{kg}$ L-glutamine to the pre-started diet.

Keywords: amino acids, additives.birds, coccidiosis, intestinal integrity

\section{RESUMO}

Quinhentos frangos de corte machos da linhagem Cobb foram distribuídos em delineamento em blocos casualizados com cinco tratamentos, quarto repetições e 25 aves por unidade experimental para avaliar os efeitos da adição de L-glutamina na dieta das aves sem anticoccidiano e promotor de crescimento. As dietas experimentais continham L-glutamina em diferentes níveis $(0,0 ; 5,0 ; 10,0 ; 15.0$ e $20,0 \mathrm{~g} / \mathrm{kg})$. $\mathrm{O}$ experimento foi conduzido com frangos de corte de 1 a 42 dias de idade. As variáveis avaliadas foram consumo de ração, conversão alimentar, ganho de peso, mortaliade, coeficientes de digestibilidade da matéria seca, da proteína bruta e do extrato etéreo, rendimento de carcaça e morfometria do intestino delgado. Os dados foram submetidos à análise de regressão polinomial. As médias foram comparadas pelo teste Tukey. - Considerou-se o erro tipo I sendo $\mathrm{P} \leq 0,05$. O nível de L-glutamina na dieta influenciou a conversão alimentar dos frangos de 1 a 7 dias de idade, sendo melhor com $10,0 \mathrm{~g} / \mathrm{kg}$ L-glutamina. Rendimento de carcaça e coeficientes de digestibilidade não foram afetados pelos níveis de glutamina na dieta. Adição de L-glutamina influenciou a profundidade de cripta do intestino delgado aos 18 e 42 dias de idade. Recomenda-se a adição de $10,0 \mathrm{~g} / \mathrm{kg}$ L-glutamina na dieta pré-inicial das aves.

Palavras-chave: aminoácidos, aditivos, aves, coccidiose, integridade intestinal 


\section{INTRODUCTION}

Glutamine is a non-essential amino acids that plays important roles in the organism in nitrogen transport, as glutamate precursor and in cell proliferation, especially faster growing cell proliferation, such as enterocytes. Glutamine is crucial in many situations related to the cell proliferation process. It had related that glutamine plays role in protein synthesis, anabolic/trophic substance for muscle and intestine, controls acid-base balance, hepatic ureagenesis, gluconeogenesis, fuel for intestinal enterocytes, fuel and nucleic acid precursor, ammonia scavenger, nitrogen donor, nitrogen transport, precursor of d-aminobutyric acid, shuttle for glutamate. (YOUNG \& AJAMI, 2001)

Despite having been classified as nonessential, there is increasing evidence that supplemental glutamine may be beneficial, not only in hypercatabolic states, but also in the maintenance of optimal health and maximal rates of growth of healthy animals (WATFORD et al., 2011).

According to Bartell \& Batal (2007), the addition of $1 \%$ glutamine to the diet of broiler chicks improves growth performance and may stimulate development of the gastrointestinal tract and humoral immune response. Likewise, Caldara et al. (2010) found that glutamine accelerated the carbon substitution speed of the intestinal mucous membrane, evidencing its beneficial action in the recovery of the intestine structure after weaning in weaned piglets.

Antibiotics have been used as feed additive in poultry rations as a growth promoter to improve performance by reducing pathogens. However, there is increasing pressure to reduce or eliminate the use of antibiotics in poultry feed due to the negative human health issue of antibiotic resistance (SUN et al., 2005). Watford et al. (2011) reported that during times of severe trauma or infection, there is an increase in glutamine requirement by tissues such as the immune cells as well as kidneys and liver. In addition, the supplementation of glutamine is a strategy that would be beneficial on mucosal development of the small intestine of broilers fed growth promoter-free diets.

In this context, this experiment was conducted in order to evaluate glutamine supplementation on anticoccidial agents and growth promoter-free diets for broilers and verify its effects on nutrients digestibility, productive performance, carcass yield and morphology of small intestine of broilers.

\section{MATERIAL AND METHODS}

Five hundred commercial male Cobb broilers, from 1 to 42 days old were used. The chicks mean initial body weight was $38.11 \pm 0.61 \mathrm{~g}$.

Broilers were randomly distributed in 20 floor pens of $1.25 \times 1.25 \mathrm{~m}$ each. An 8 -cm-deep rice rusk was used as poultry manure litter over a concrete floor. Light was provided for $24 \mathrm{~h}$ daily, using incandescent bulbs.

Broilers were allotted in a randomized blocks design with five treatments, four replicates and 25 birds per experimental unit. The localization of box inside conventional shed was adopted as blocks criteria.

Corn and soybean meal diets were formulated to meet broiler requirements (ROSTAGNO et al., 2005) for all nutrients and no anticoccidial agents 
and antibiotics were used as growth promoters (Table 1). The feeding program adopted had four phases as follows: pre-starter (1 to 7 days old); starter (8 to 21 days old), growth (22 to 35 days old) and finishing phase (36 to 42 days old). A basal diet with no L-glutamine supplementation was formulated for each production phase. Four diets were prepared from the basal diet by varying the levels of L-Glutamine, totaling five experimental diets containing five levels of L-Glutamine $(0.0 ; 5.0 ; 10.0 ; 15.0$ and $20.0 \mathrm{~g} / \mathrm{kg}$ ). L-glutamine was added to the basal diet at the expense of inert.

Table 1. Composition of basal diets $(\mathrm{g} / \mathrm{kg})$

\begin{tabular}{|c|c|c|c|c|}
\hline Feed ingredients & Pre-starter & Starter & Growth & Finishing \\
\hline Corn & 513.3 & 532.6 & 562.0 & 602.4 \\
\hline Soybean Meal & 386.2 & 362.8 & 326.5 & 287.4 \\
\hline Vegetable oil & 36.3 & 45.5 & 54.9 & 55.0 \\
\hline Inert & 20.0 & 20.0 & 20.0 & 20.0 \\
\hline Dicalcium phosphate & 19.2 & 18.2 & 16.8 & 15.3 \\
\hline Limestone & 8.4 & 8.1 & 7.7 & 7.4 \\
\hline Salt & 4.5 & 4.4 & 4.2 & 4.0 \\
\hline L-lysine $\mathrm{HCl}$ & 3.8 & 2.2 & 2.0 & 2.6 \\
\hline Dl-methionine & 3.7 & 2.6 & 2.4 & 2.4 \\
\hline L-threonine & 1.6 & 0.7 & 0.5 & 0.7 \\
\hline Vitamin Premix ${ }^{1}$ & 2.0 & 2.0 & 2.0 & 2.0 \\
\hline Mineral Premix ${ }^{2}$ & 0.5 & 0.5 & 0.5 & 0.5 \\
\hline Total & 100 & 100 & 100 & 100 \\
\hline \multicolumn{5}{|c|}{ Composition calculated $(\mathrm{g} / \mathrm{kg})$} \\
\hline Crude protein & 221.1 & 211.4 & 197.3 & 183.1 \\
\hline Metabolizable energy $(\mathrm{kcal} / \mathrm{kg})$ & 2960 & 3050 & 3150 & 3200 \\
\hline Dig. lysine (\%) & 13.7 & 11.9 & 11.0 & 7.0 \\
\hline Dig. methionine + cystine $(\%)$ & 9.6 & 8.4 & 7.9 & 7.5 \\
\hline Calcium & 9.4 & 8.9 & 8.3 & 7.7 \\
\hline Available phosphorus & 4.7 & 4.4 & 4.1 & 3.8 \\
\hline \multicolumn{5}{|c|}{$\begin{array}{l}\text { Content per kg premix: vit. A, 1,680.000 UI; vit.D 3, } 400.000 \mathrm{UI} \text {; vit. E, } 3,500 \mathrm{mg} \text {; vit. K, } 360 \mathrm{mg} \text {; vit. } \\
\text { B1, } 436.50 \mathrm{mg} \text {; vit. B2, 1,200 mg; vit. B6, } 624 \mathrm{mg} \text {; vit. B12, 2,400mcg; folacin, } 200 \mathrm{mg} \text {; panthotenic } \\
\text { acid, 3,120 mg; niacin, 8,400 mg; biotin, 10,000 mcg. } \\
\text { 'Content per kg premix: zinc, 17,500 ppm; iron, 12,500 ppm; copper, 2,000 ppm; iodine, } 187.50 \mathrm{ppm} \text {; } \\
\text { selenium, } 75 \mathrm{ppm} \text {. }\end{array}$} \\
\hline
\end{tabular}

Animals were fed ad libitum and had free access to water through the experiment period.

The effects of dietary treatment on broiler performance were determined. Feed intake, body weight gain, feed conversion ratio and mortality were assessed in the periods from 1 to 7 days,
1 to 21 days and 1 to 42 days of age. Mortality was transformed using arc sen $((\%$ Mort./100) + 0.05) 0.5).

At the end of the experiment, three birds per experimental unit were randomly slaughtered by cervical dislocation for carcass yield determination, which was carried out using eviscerated carcass 
without feet and head, in relation to weight at fast live weight.

A total of one hundred 15-day-old broilers, were used at the beginning of the experiment to determine the digestibility coefficient of the dry matter, nitrogen, ether extract and of the experimental diets. Broilers were randomly distributed according to the five experimental diets and housed in battery cages. The method used was the total excreta collection. Birds were submitted to a 3-day-period of adaptation to the experimental diets and four days of excreta collection. The excreta collected were stored in a freezer $\left(-20^{\circ} \mathrm{C}\right)$. The analyses of dry matter, ether extract and nitrogen of diets and excreta were made on Laboratory of Animal Nutrition of the Faculty of Veterinary and Animal Science of UFG, according to methodology described by Silva \& Queiroz (2002).

For the histomorphometry study, four birds per treatment at 18 and 42 days of age were slaughtered after six hours of fasting. Segments of $3.0 \mathrm{~cm}$ of duodenum, jejunum and ileum were collected, washed in saline, opened along its mesenteric border, stretched by the tunica serosa and then fixed in $10 \%$ neutral formalin for 24 hours. Subsequently, the material was washed in $70 \%$ alcohol and then submitted to dehydration, by treatment with increasing concentrations of ethanol (70-100\%). The samples were cleared in xylene and paraffin embedded. Slides were prepared for each segment with 14 semi-serial cuts with a seven micrometers thick, stained with hematoxylin and eosin (HE) according to the methodology of Luna (1968). After the staining procedure, with the aid of an optical microscope coupled to an image analyzing system Axio Vision 3.0 (Zeiss $\AA$ ), 10 measurements of villi height and crypts depth of duodenum, jejunum and ileum were made per slide, resulting in 60 scans per treatment. Measurements of villi height were performed as described by Andrade et al. (2008).

Data were submitted to ANOVA using the SAS (Statistical Analysis System version 7.5) software. The data obtained were submitted to polynomial regression analysis, decomposing the degrees of freedom of linear and quadratic models. Was considered a type I error set at $\mathrm{P} \leq 0.05$.

\section{RESULTS AND DISCUSSION}

During the pre-starter phase ( 1 to 7 days old) there were no effects of L-glutamine on feed intake, body weight gain and mortality of chicks (P>0.05) (Table 2). Similarly, Maiorka et al. (2000) did not find differences on performance of broilers fed $10.0 \mathrm{~g} / \mathrm{kg}$ L-glutamine during 1 to 7 days of age.

Zavarize et al. (2011) verified that glutamine supplementation (1\%) improved body weight, feed intake and feed conversion in the first week of broiler chicks housed in alternative breeding system.

The feed conversion ratio has improved linearly with L-glutamine supplementation $\quad(\mathrm{P}<0.05) \quad$ (Table 2, Figure 1). This result suggests positive effects of glutamine on intestinal cell maturation, including indirect effects on nutrient utilization efficiency.

Caldara et al. (2010) conducted an experiment to evaluate the influence of glutamine on the carbon turnover in the intestinal mucosa of weaned piglets and verified that that supplementation of $10.0 \mathrm{~g} / \mathrm{kg}$ glutamine in diets accelerated the process, indicating positive effect on tissue renovation. 
Rev. Bras. Saúde Prod. Anim., Salvador, v.15, n.3, p.637-648 jul./set., 2014 http://www.rbspa.ufba.br ISSN 15199940

Table 2. Mean values of performance and mortality of 1 to 7 days old broilers fed different levels of L-glutamine

\begin{tabular}{lccccc}
\hline L-Glutamine $(\mathrm{g} / \mathrm{kg})$ & $\begin{array}{c}\text { Final } \\
\text { weight }(\mathrm{g})\end{array}$ & $\begin{array}{c}\text { Feed intake } \\
(\mathrm{g})\end{array}$ & $\begin{array}{c}\text { Feed } \\
\text { conversion } \\
\text { ratio }\end{array}$ & $\begin{array}{c}\text { Body } \\
\text { Weight Gain } \\
(\mathrm{g})\end{array}$ & $\begin{array}{c}\text { Mortality } \\
(\%)\end{array}$ \\
\hline 0.0 & 172.6 & 135.1 & 1.045 & 134.2 & 2.09 \\
5.0 & 167.6 & 131.8 & 1.043 & 128.4 & 0.00 \\
10.0 & 167.4 & 135.2 & 1.011 & 129.2 & 1.03 \\
15.0 & 166.2 & 132.3 & 1.015 & 127.3 & 1.02 \\
20.0 & 167.9 & 132.8 & 1.019 & 129.4 & 0.00 \\
\hline P value & 0.117 & 0.492 & 0.024 & 0.077 & 0.415 \\
\hline CV $(\%)$ & 2.21 & 2.82 & 1.96 & 2.78 & 16.25 \\
\hline CV
\end{tabular}

$\mathrm{CV}=$ coefficient of variation

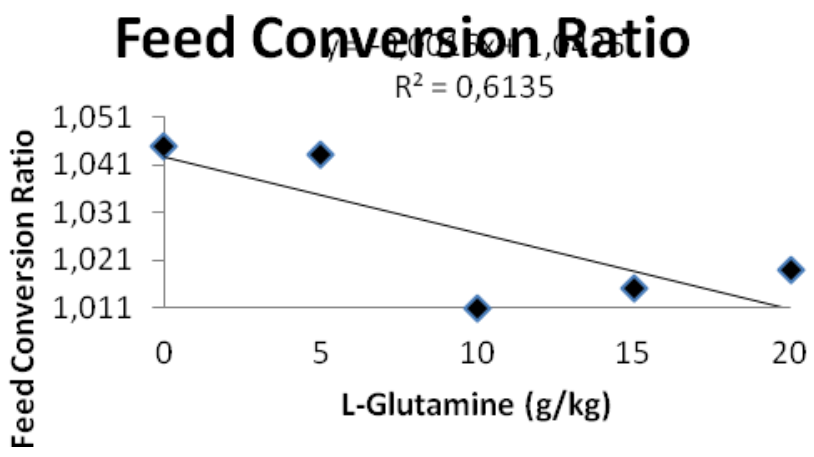

Figure 1. Feed Conversion Ratio of 1 to 7 days old broilers fed different levels of Lglutamine

There was no improvement in feed intake, feed conversion ratio and body weight gain of broilers from 1 to 21 days of age due to the addition of glutamine $(\mathrm{P}>0.05)$ (Table 3). However, L-glutamine supplementation reduced linearly the mortality of broilers $(\mathrm{P}<0.05)$ (Figure 2). It is possible that coccidiosis occurred in broilers at this phase, since birds were housed in floor pen with no coccidial agents. In this condition, glutamine is able to decrease the mortality of broilers from 1 to 21 days of age. According to Bartell \& Batal (2007), the addition of $1 \%$ glutamine to the diet of broiler chicks improves humoral immune response, presenting higher IgA concentrations in the serum and bile and higher $\operatorname{IgG}$ concentrations in the serum compared with birds fed no glutamine.

Considering the total rearing period (1 to 42 days of age), effect of L-Glutamine on broiler performance $(\mathrm{P}>0.05)$ was not verified (Table 4). These results are similar to what was found by Maiorka et al. (2000), who concluded that $10.0 \mathrm{~g} / \mathrm{kg}$ L-Glutamine had no effect on feed conversion ratio and body weight gain of 49-day-old broilers. When total rearing period is considered, the effects of glutamine are not evident or significant. Other studies carried out with broiler chicks fed glutamine presented similar results to this. (ZAVARIZE et al., 2011) 
Rev. Bras. Saúde Prod. Anim., Salvador, v.15, n.3, p.637-648 jul./set., 2014 http://www.rbspa.ufba.br ISSN 15199940

Table 3. Mean values of performance and mortality of broilers at 1 to 21 days of age fed different levels of L-glutamine

\begin{tabular}{lccccc}
\hline $\begin{array}{l}\text { L-Glutamine } \\
(\mathrm{g} / \mathrm{kg})\end{array}$ & $\begin{array}{c}\text { Final } \\
\text { weight }(\mathrm{kg})\end{array}$ & $\begin{array}{c}\text { Feed intake } \\
(\mathrm{kg})\end{array}$ & $\begin{array}{c}\text { Feed conversion } \\
\text { ratio }\end{array}$ & $\begin{array}{c}\text { Body Weight } \\
\text { Gain }(\mathrm{kg})\end{array}$ & $\begin{array}{c}\text { Mortality } \\
(\%)\end{array}$ \\
\hline 0.0 & 1.02 & 1.17 & 1.266 & 0.97 & 6.58 \\
5.0 & 0.99 & 1.15 & 1.268 & 0.94 & 5.60 \\
10.0 & 1.02 & 1.16 & 1.251 & 0.97 & 3.36 \\
15.0 & 1.00 & 1.15 & 1.249 & 0.96 & 2.27 \\
20.0 & 0.99 & 1.16 & 1.270 & 0.94 & 0.00 \\
\hline $\mathrm{P}$ value & 0.384 & 0.536 & 0.381 & 0.355 & 0.050 \\
\hline $\mathrm{CV}(\%)$ & 2.53 & 1.75 & 1.42 & 2.45 & 19.13 \\
\hline $\mathrm{CV}=$ coefficient of variation. & & & &
\end{tabular}

\section{Mortality (\%)}

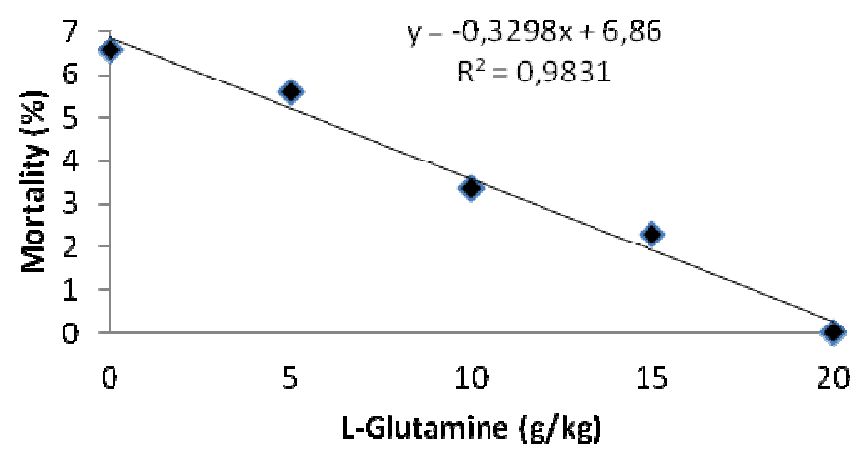

Figure 2. Feed Conversion Ratio of 1 to 21 days old broilers fed different levels of Lglutamine

Table 4. Mean values of performance and mortality of broilers at 1 to 42 days of age fed different levels of L-glutamine

\begin{tabular}{lccccc}
\hline $\begin{array}{l}\text { L-Glutamine } \\
(\mathrm{g} / \mathrm{kg})\end{array}$ & $\begin{array}{c}\text { Final } \\
\text { weight }(\mathrm{kg})\end{array}$ & $\begin{array}{c}\text { Feed intake } \\
(\mathrm{kg})\end{array}$ & $\begin{array}{c}\text { Feed } \\
\text { conversion } \\
\text { ratio }\end{array}$ & $\begin{array}{c}\text { Body } \\
\text { weight } \\
\text { gain }(\mathrm{kg})\end{array}$ & $\begin{array}{c}\text { Mortality } \\
(\%)\end{array}$ \\
\hline 0.0 & 2.90 & 4.3 & 1.643 & 2.84 & 14.9 \\
5.0 & 2.85 & 4.2 & 1.636 & 2.80 & 13.9 \\
10.0 & 2.92 & 4.4 & 1.641 & 2.86 & 12.3 \\
15.0 & 2.96 & 4.3 & 1.609 & 2.90 & 11.0 \\
20.0 & 2.87 & 4.3 & 1.637 & 2.82 & 11.8 \\
\hline P value & 0.414 & 0.190 & 0.124 & 0.407 & 0.725 \\
\hline $\mathrm{CV}(\%)$ & 2.65 & 1.95 & 1.42 & 2.70 & 15.65 \\
\hline $\mathrm{CV}=$ coefficient of variation & & & &
\end{tabular}


Rev. Bras. Saúde Prod. Anim., Salvador, v.15, n.3, p.637-648 jul./set., 2014 http://www.rbspa.ufba.br ISSN 15199940

Glutamine did not influence $(\mathrm{P}>0.05)$ carcass weight, carcass yield, cut-part yield (thigh and drumstick, wings, breast and back, abdominal fat) $(\mathrm{P}>0.05) \quad$ (Table 5). These results indicate that glutamine has no influence on protein deposition in these tissues.
L-glutamine supplementation decreased digestibility coefficient of crude protein $(\mathrm{P}<0.05)$ and did not influence digestibility coefficient of dry matter and ether extract $(\mathrm{P}>0.05)$ (Table 6).

Table 5. Mean values of carcass yield of broilers feed different levels of L-glutamine

\begin{tabular}{|c|c|c|c|c|c|c|c|c|}
\hline \multirow[b]{2}{*}{$\begin{array}{l}\text { L-Glutamine } \\
(\mathrm{g} / \mathrm{kg})\end{array}$} & \multicolumn{2}{|c|}{ Weight $(\mathrm{kg})$} & \multicolumn{6}{|c|}{ Carcass yield (\%) } \\
\hline & $\begin{array}{c}\text { Live } \\
\text { Body } \\
\text { weight }\end{array}$ & $\begin{array}{c}\text { Carcass } \\
\text { weight }\end{array}$ & Carcass & Breast & $\begin{array}{l}\text { Thigh and } \\
\text { drumstick }\end{array}$ & Wings & Back & $\begin{array}{c}\text { Abdominal } \\
\text { Fat }\end{array}$ \\
\hline 0.0 & 3.13 & 2.30 & 73.73 & 38.00 & 28.75 & 10.21 & 22.6 & 1.88 \\
\hline 5.0 & 3.07 & 2.25 & 73.35 & 38.83 & 28.30 & 9.78 & 22.5 & 1.73 \\
\hline 10.0 & 3.07 & 2.26 & 73.63 & 38.07 & 29.16 & 10.07 & 22.1 & 1.51 \\
\hline 15.0 & 3.11 & 2.29 & 73.73 & 39.51 & 27.32 & 10.03 & $2 \overline{2} .3$ & 1.54 \\
\hline 20.0 & 3.03 & 2.23 & 73.79 & 39.18 & 28.58 & 10.01 & 21.9 & 1.76 \\
\hline $\mathrm{P}$ value & 0.510 & 0.678 & 0.993 & 0.272 & 0.072 & 0.351 & 0.74 & 0.246 \\
\hline $\mathrm{CV}(\%)$ & 4.64 & 5.78 & 0.03 & 5.14 & 5.55 & 4.99 & 6.18 & 26.78 \\
\hline
\end{tabular}

$\mathrm{CV}=$ coefficient of variation.

Table 6. Digestibility coefficients of dry matter (DMDC), crude protein (CPDC) and ether extract (EEDC) of broilers fed different levels of L-glutamine

\begin{tabular}{lccc}
\hline L-Glutamine $(\mathrm{g} / \mathrm{kg})$ & DMDC & CPDC & EEDC \\
\hline 0.0 & 0.76 & 0.72 & 0.89 \\
5.0 & 0.75 & 0.70 & 0.88 \\
10.0 & 0.77 & 0.72 & 0.90 \\
15.0 & 0.75 & 0.69 & 0.89 \\
20.0 & 0.76 & 0.67 & 0.89 \\
\hline P value & 1.122 & 0.012 & 0.478 \\
\hline CV $(\%)$ & 1.18 & 2.69 & 1.34 \\
\hline
\end{tabular}

${ }^{1}$ Linear regression $\mathrm{y}=71.977758-2.1516 \mathrm{x}, \mathrm{R}^{2}=0.57$.

$\mathrm{CV}=$ coefficient of variation.

Glutamine did not affect intestinal villi height in either of the studied periods (Tables 7 and 8). This result was unexpected because glutamine is supposed to have an effect on cell proliferation. However, Zavarize et al. (2011) reported that glutamine did not affect villi height and crypt depth of small intestine of 42-day-old broilers.

Crypt depths in the duodenum, jejunum and ileum (Table 7) were significantly longer in 18 and 42- day-old birds fed diets supplemented with glutamine $(\mathrm{P}<0.05)$ (Figure 3, 4, 5, 6, 7 and 8). Levels of glutamine influenced crypt 
Rev. Bras. Saúde Prod. Anim., Salvador, v.15, n.3, p.637-648 jul./set., 2014 http://www.rbspa.ufba.br ISSN 15199940

depth quadratically. However, the model showed $\mathrm{R}^{2}$ lower than 0.3 , indicate model have a low correlation. Considering broilers at 18 days of age, the better glutamine inclusion to improve crypt depth of duodenum and ileum was $20.0 \mathrm{~g} / \mathrm{kg}$ and to improve crypt depth of jejunum was $10.0 \mathrm{~g} / \mathrm{kg}$. 42-day-old broilers had higher crypt depth of duodenum, jejunum and ileum at $10.0,5.0$ and $20.0 \mathrm{~g} / \mathrm{kg}$ of glutamine, respectively.
There is a consensus in literature that intestinal morphology is influenced by the addition of glutamine to the ration. However, results differ regarding the effects of glutamine on intestinal villi height and crypt depth. Some authors verified that glutamine only influences villi height in swine (MOLINO et al., 2012), Nile tilapia juvenile (SILVA et al., 2010) and broilers (BARTELL \& BATAL, 2007). Other authors verified that glutamine influences crypt depth (MAIORKA et al., 2000).

Table 7. Mean values of villi height and crypt depth of 18-day-old broilers fed different levels of L-glutamine

\begin{tabular}{lcccccc}
\hline \multirow{2}{*}{$\begin{array}{l}\text { L-Glutamine } \\
(\mathrm{g} / \mathrm{kg})\end{array}$} & \multicolumn{3}{c}{ Crypt $(\mu \mathrm{m})$} \\
\cline { 2 - 7 } & Duodenum & Jejunum & Ileum & Duodenum & Jejunum & Ileum \\
\hline 0.0 & 197.03 & 185.36 & 155.18 & 1.152 .7 & 688.5 & 629.6 \\
5.0 & 197.48 & 209.19 & 163.58 & 1.140 .3 & 920.8 & 573.4 \\
10.0 & 200.81 & 266.38 & 156.56 & 815.5 & 842.9 & 677.0 \\
15.0 & 218.32 & 236.05 & 184.13 & 883.9 & 824.8 & 589.5 \\
20.0 & 252.60 & 150.90 & 211.30 & 1.224 .6 & 738.7 & 583.4 \\
\hline P value & 0.0001 & 0.0005 & 0.0001 & 0.1231 & 0.0678 & 0.9109 \\
\hline CV $(\%)$ & 2.08 & 2.82 & 2.33 & 3.59 & 2.45 & 3.57 \\
\hline Regression & Qd & Qd & Qd & ns & ns & $\mathrm{ns}$ \\
\hline Qd-Quadratic regression; CV $=$ coefficient of variation. & & & &
\end{tabular}

Table 8. Mean values of villi height and crypt depth of 42-day-old broilers fed different levels of L-glutamine

\begin{tabular}{|c|c|c|c|c|c|c|}
\hline \multirow{2}{*}{$\begin{array}{c}\text { L- } \\
\text { Glutamine } \\
(\mathrm{g} / \mathrm{kg})\end{array}$} & \multicolumn{3}{|c|}{ Crypt $(\mu \mathrm{m})$} & \multicolumn{3}{|c|}{ Villi $(\mu \mathrm{m})$} \\
\hline & Duodenum & Jejunum & Ileum & Duodenum & Jejunum & Ileum \\
\hline 0.0 & 288.50 & $169.13 b$ & 149.21 & 1227.7 & 824.2 & 555.9 \\
\hline 5.0 & 285.19 & $234.52^{\mathrm{a}}$ & 189.93 & 1072.1 & 1093.8 & 562.8 \\
\hline 10.0 & 364.98 & $226.06^{\mathrm{a}}$ & 151.61 & 1259.1 & 1256.6 & 609.7 \\
\hline 15.0 & 299.82 & $210.28^{\mathrm{a}}$ & 158.10 & 1514.1 & 1055.0 & 593.4 \\
\hline 20.0 & 308.05 & $238.26^{\mathrm{a}}$ & 191.77 & 1369.9 & 1064.1 & 493.9 \\
\hline $\mathrm{P}$ value & 0.0531 & 0.0004 & 0.0121 & 0.1482 & 0.0654 & 0.1750 \\
\hline $\mathrm{CV}(\%)$ & 1.92 & 2.69 & 2.53 & 2.58 & 3.23 & 2.40 \\
\hline Regression & $\mathrm{Qd}$ & Qd & Qd & $\mathrm{ns}$ & ns & $\mathrm{ns}$ \\
\hline
\end{tabular}

Qd-Quadratic regression; CV = coefficient of variation. 


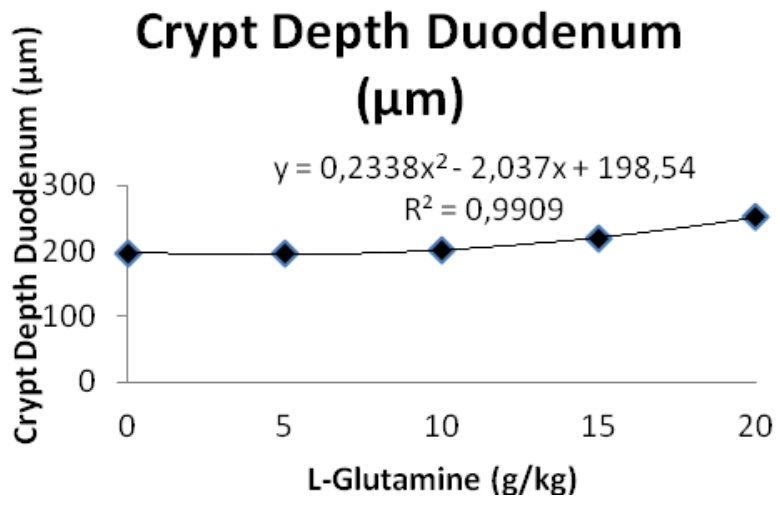

Figure 3. Feed Crypt Depth duodenum of 18 days old broilers fed different levels of L-glutamine

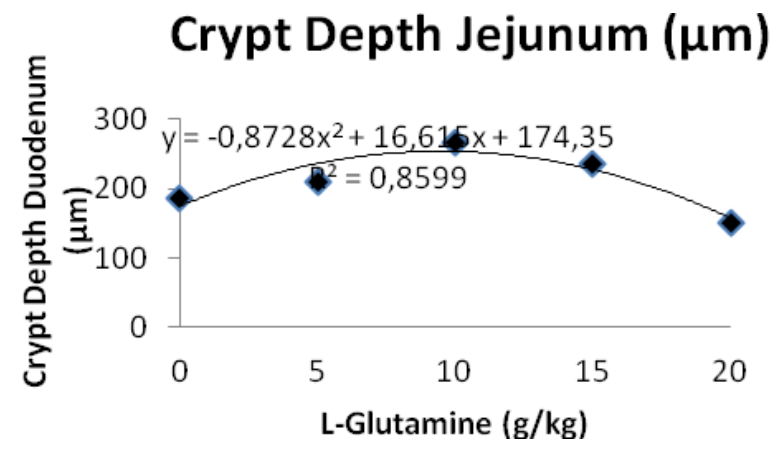

Figure 4. Feed Crypt Depth Jejunum of 18 days old broilers fed different levels of L-glutamine

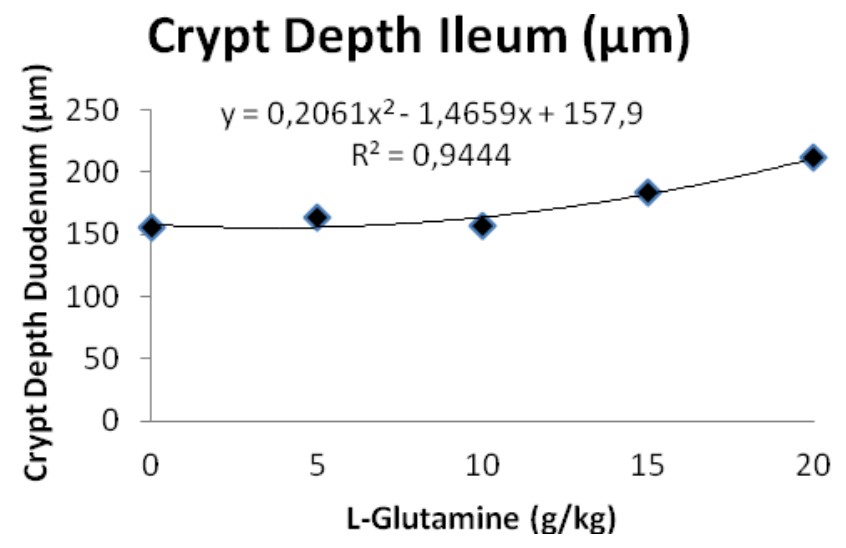

Figure 5. Feed Crypt Depth Ileum of 18 days old broilers fed different levels of Lglutamine 


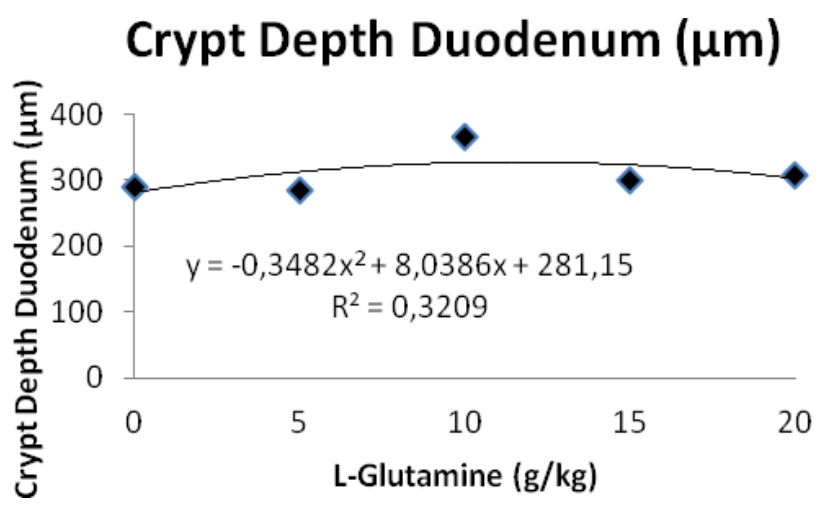

Figure 6. Feed Crypt Depth Duodenum of 42 days old broilers fed different levels of Lglutamine

\section{Crypt Depth Jejunum ( $\mu \mathrm{m})$}

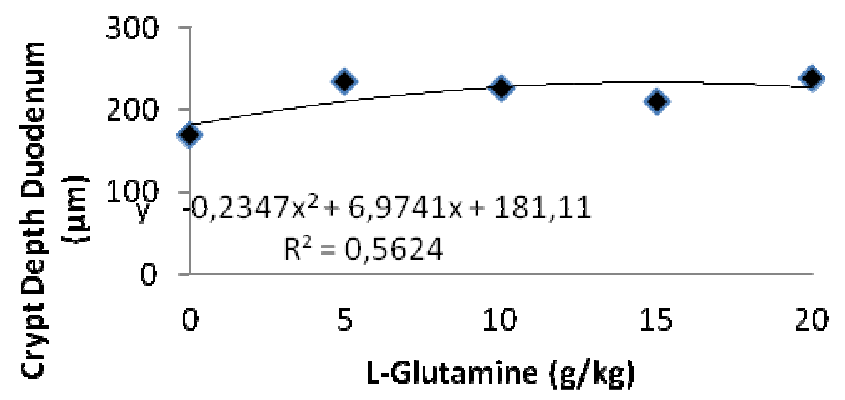

Figure 7. Feed Crypt Depth Jejunum of 42 days old broilers fed different levels of L-glutamine

\section{Crypt Depth Ileum ( $\mu \mathrm{m})$}

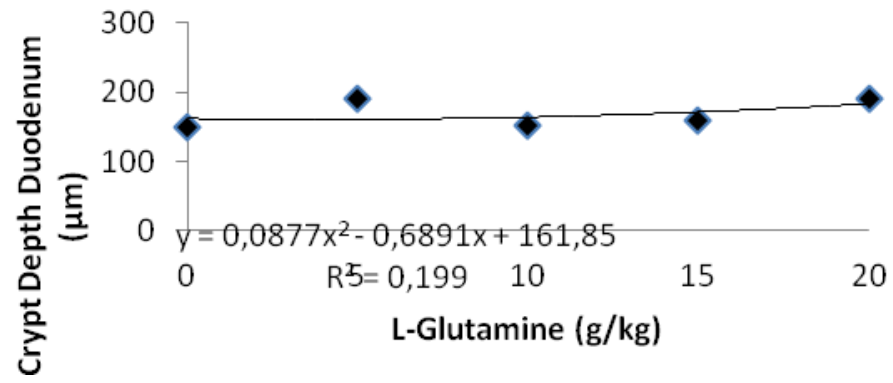

Figure 8. Feed Crypt Depth Ileum of 42 days old broilers fed different levels of L-glutamine 
Rev. Bras. Saúde Prod. Anim., Salvador, v.15, n.3, p.637-648 jul./set., 2014 http://www.rbspa.ufba.br ISSN 15199940

In most studies, the inclusion of $10.0 \mathrm{~g} / \mathrm{kg}$ of glutamine is enough to ensure the performance of broilers and improve mucosal development of small intestine.

The villous:crypt ratio, which is the result of the division between the measurement of villous height and the depth of its respective crypt, was not affected by the inclusion of glutamine in ration (Table 9).

Studying the influence of glutamine supplementation in the ration on performance and on the intestinal structure development of broiler chickens, Maiorka et al. (2000) reported that $1 \%$ glutamine supplementation in the ration did not influence broiler chicken performance during the different phases of growth; however, glutamine changes villous height, crypt depth and villous:crypt ratio in the duodenum, as well as villous height in the ileum at 7 days of age.

Table 9. Mean values of villous:crypt ratio of broilers fed different levels of L-glutamine

\begin{tabular}{lllllll}
\hline \multirow{2}{*}{$\begin{array}{l}\text { L-Glutamine } \\
(\mathrm{g} / \mathrm{kg})\end{array}$} & \multicolumn{3}{c}{ villous:crypt at 18 days } & \multicolumn{3}{c}{ villous:crypt at 42 days } \\
\cline { 2 - 7 } & Duodenum & Jejunum & Ileum & Duodenum & Jejunum & Ileum \\
\hline 0.0 & 5.80 & 3.86 & 4.01 & 4.11 & 5.01 & 3.87 \\
5.0 & 5.92 & 4.64 & 3.82 & 3.61 & 5.35 & 2.97 \\
10.0 & 3.75 & 3.38 & 4.22 & 3.43 & 5.56 & 3.87 \\
15.0 & 5.08 & 3.79 & 3.25 & 5.09 & 5.41 & 3.78 \\
20.0 & 4.96 & 5.33 & 2.78 & 4.45 & 4.48 & 2.56 \\
\hline P value & 0.338 & 0.337 & 0.009 & 0.2317 & 0.5081 & 0.4407 \\
CV $(\%)$ & 19.31 & 26.15 & 18.51 & 17.08 & 16.20 & 26.27 \\
Regression & ns & ns & ns & ns & ns & ns \\
\hline CV
\end{tabular}

$\mathrm{CV}=$ coefficient of variation.

In conclusion, the results indicated that the addition of $10.0 \mathrm{~g} / \mathrm{kg}$ L-glutamine to the pre-starter and starter diets for broilers chicks improves feed conversion ratio and mucosal intestinal development. The supplementation of L-glutamine after the starter phase did not improve broiler performance, carcass yield and nutrients digestibility.

\section{REFERENCES}

ANDRADE, M.A.; MESQUITA, A.J.; STRINGHINI, J.H.; PEDROSO, A.A.; LEANDRO, N.S.M.; CAFÉ, M.B.; MATTOS, M.S. Infecção experimental de embriões de frango de corte com Salmonella enterica sorovar Enteritidis fagotipo 4. Arquivo Brasileiro de Medicina Veterinária e Zootecnia, v.60, n.5, p.1110-1117, 2008.

BARTELL, S.M.; BATAL, A.B. The effect of supplemental glutamine on growth performance, development of the gastrointestinal tract, and humoral immune response of broilers. Poultry Science, v.86, p.1940-1947, 2007.

CALDARA, F.R.; DUCATTI, C.; BERTO, D.A.; DENADAI, J.C.; GARCIA, R.G.; FERREIRA, V.M.O.S. Glutamina e turnover do carbono da mucosa intestinal de leitões desmamados. Revista Brasileira de Zootecnia, v.39, n.12, p.2664-2669, 2010. 
Rev. Bras. Saúde Prod. Anim., Salvador, v.15, n.3, p.637-648 jul./set., 2014 http://www.rbspa.ufba.br ISSN 15199940

LOBLEY, G.E.; HOSKIN, S.O.; MCNEIL, C.J. Glutamine in Animal Science and Production. The Journal of Nutrition, v.131, p.2525-2531, 2001.

LUNA, L.G. Manual of Histologic

Staining Methods of the Armed Forces Institute of Pathology. 3.ed. New York: McGraw - Hill, 1968. 258p.

MAIORKA, A.; SILVA, A.V.F.; SANTIN, E.; BORGES, S.A.; BOLELI, I.C.; MACARI, M. Influência da suplementação de glutamina sobre o desempenho e o desenvolvimento de vilos e criptas do intestino delgado de frangos de corte. Arquivo Brasileiro de Medicina Veterinária e Zootecnia, v.52, n.5, p.487-490, 2000.

MOLINO, J.P.; DONZELE, J.L.; OLIVEIRA, R.F.M.; SARAIVA, A.; HAESE, D.; FORTES, E.I. L-glutamine and L-glutamate in diets with different lactose levels for piglets weaned at 21 days of age. Revista Brasileira de Zootecnia, v.41, n.1, p.98-105, 2012.

ROSTAGNO, H.S.; ALBINO, L.F.T.; DONZELE, J.L.; GOMES, P.C.; YOUNG, V.R.; AJAMI, A.M. Glutamine: the emperor or his Clothes? The journal of Nutrition, v.131, p.2449-2459, 2001. Supl.

ZAVARIZE, K.C.; SARTORI, J.R.; PELÍCIA, V.C.; PEZZATO, A.C.; ARAUJO, P.C.; STRADIOTTI, A.C.; MADEIRA, L.A. Glutamina e nucleotídeos na dieta de frangos de corte criados no sistema alternativo. Archivos de Zootecnia, v.60, n.232, p.913-920, 2011.
OLIVEIRA, R.F.; LOPES, D.C.; FERREIRA, A.S.; BARRETO, S.L.T. Tabelas brasileiras para aves $\mathrm{e}$ suínos: composição de alimentos e exigências nutricionais. Viçosa: Universidade Federal de Viçosa, 2005. 141p.

SILVA, L.C.R.; FURUYA, W.M.; NATALI, M.R.M.; SCHANBER, C.R.; SANTOS, L.D.dos; VIDAL, L.V.O. Desempenho e morfometria intestinal de juvenis de tilápia-do-nilo alimentados com dietas suplementadas com L-glutamina e L-glutamato.

Revista Brasileira de Zootecnia v. 39, n. 6, p.1175-1179, 2010.

SILVA, D.J.; QUEIROZ, A.C. Analise de alimentos: métodos químicos e biológicos. 3. ed. Viçosa: Universidade Federal de Viçosa, 2002. 235p.

WATFORD, M.; KUTSCHENKO, M.; NOGUEIRA, E.T. Optimal dietary glutamine for growth and development. Revista Brasileira de Zootecnia, v.40, p.402-408, 2011.

Data de recebimento: 05/08/2013

Data de aprovação: 11/08/2014 